\title{
Optimization of exopolysaccharide production by response surface methodology from Enterococcus faecium isolated from the fermented foods of Western Himalaya
}

\author{
Aditi Chauhan ${ }^{1}$, Sarbjit Singh Kanwar ${ }^{2 *}$ \\ ${ }^{1}$ Department of Microbiology, Panjab University, Chandigarh-160014, India \\ ${ }^{2}$ Department of Microbiology, College of Basic Sciences, CSK HP KV, Palampur-176061, India \\ Corresponding Author: sskanwar1956@gmail.com
}

Available online at: www.isroset.org

Received: 16/Jul/2019, Accepted: 02/Aug/2019, Online: 31/Aug/2019

\begin{abstract}
$\overline{\text { Abstract - Eleven potential probiotic bacteria isolated from traditional fermented foods of Western Himalaya were screened }}$ for exopolysaccharide production by using ruthenium red milk agar and 3 isolates viz. AdF1, AdF2 and AdF3 were found to be positive. The quantitative analysis of exopolysaccharide production was done by phenol sulphuric acid method where AdF3 showed highest EPS production. For optimization of exopolysaccharide production carbon source, nitrogen source, $\mathrm{pH}$, temperature and incubation time were optimized by using One Variable at a Time approach (OVAT) followed by Response Surface Methodology (RSM). Lactose was found to be the best carbon source (5\% for AdF1 and $6 \%$ for AdF2 \& AdF3) and yeast extract as the best nitrogen source (13.82\% for AdF1 and $14.51 \%$ for AdF2 \& AdF3). The optimum $\mathrm{pH}$, temperature and incubation time were $6.75,37^{\circ} \mathrm{C}$ and $60 \mathrm{~h}$, respectively for all the isolates. Under optimized conditions, an overall increase of 1.55, 1.37 and 1.42 folds in EPS production was observed with AdF1, AdF2 and AdF3, respectively.
\end{abstract}

Keywords-Exopolysaccharide, Enterococcus faecium, Response surface methodology

\section{INTRODUCTION}

Lactic Acid Bacteria (LAB) are the important flora of several indigenous fermented foods which are consumed and traditionally prepared in the tribal areas of Himachal Pradesh. It is not surprising that their consumption has long been associated with good health as they act as probiotics [1]. The LAB are evidenced to be good probiotics as they accelerate the growth of beneficial microbial gut flora and have been proven effective against diarrhoea, irritable bowel disorder, allergies, stimulation of immunity, lactose intolerance etc. [2-4]. Some strains of LAB divert a minute fraction of fermentable sugars for the biosynthesis of exopolysaccharides which are receiving increased attention because of their "food-grade" status" [5-8].

Exopolysaccharides (EPSs) are biopolymers, secreted by several microorganisms and are important as a natural additive in the food industry [9]. These high molecular weight polymers generally consist of monosaccharides and some non-carbohydrate substitutes such as acetate, pyruvate, succinate and phosphate [10]. These are composed of either a single type of sugar monomer (homopolysaccharides) or several types of monomers (heteropolysaccharides). All of these factors determine the rheological and health-promoting properties of EPS [11]. EPSs are located outside the cell wall, which results in the formation of mucoid and slimy colonies. They can either be tightly attached to the cell surface (capsular polysaccharides) or released as extracellular slime in the surroundings of the cell [12].

Exopolysaccharides from LAB have mainly found their most valuable application in the improvement of the rheology, texture and mouthfeel of fermented milk products [13]. Today, there is high consumer demand for smooth and creamy fermented milk products with low fat or sugar content, low levels of additives, with cost effectiveness and all these criteria make EPSs a viable alternative [14]. Also, EPSs remain in the gastrointestinal tract for a longer time, thus enhance the colonization of probiotic bacteria $[15,16]$. In addition to this LAB EPSs have been claimed to have antitumor effects, immunostimulatory activity and they also lower the blood cholesterol level $[17,18]$.

Most bacteria produce EPS under all conditions, but the quantity of EPS is strain dependent and is affected by the nutritional and environmental conditions. Therefore, it is possible to enhance polymer production by manipulating the cultural conditions [19]. Thus, the present study aimed to screen EPS producing bacteria, from the indigenous 
microorganisms isolated from various traditional fermented foods of Himachal Pradesh [20] and to further, optimize the production of the EPS from the efficient isolates by one variable at a time approach followed by Response surface methodology (RSM).

\section{METHODOLOGY}

Bacterial strains and growth conditions: The microorganisms viz. Enterococcus faecium (Adf 1, Adf 2, Adf 3), Bacillus coagulans (Adf 4), Lactobacillus Plantarum (Adf 5, Adf 6), Lactobacillus fermentum (Adf 7, Adf 8, Adf 9), Lactobacillus Plantarum (Adf 10), Enterococcus faecium (Adf 11) already isolated from various fermented food products and characterised [20], were maintained on Man Rogosa Sharpe (MRS) medium at 370C.

Screening for exopolysaccharide production: Exopolysaccharide producing microorganisms were evaluated as per the method reported by Mora et al. [22]. Overnight cultures were spotted on the surface of plates containing ruthenium red milk agar (skim milk powder $10 \%$ $\mathrm{w} / \mathrm{v}$, sucrose $1 \% \mathrm{w} / \mathrm{v}$, ruthenium red $0.08 \mathrm{~g} / \mathrm{L}$ and agar $1.5 \%$ $\mathrm{w} / \mathrm{v})$. After incubation at $370 \mathrm{C}$ for $24 \mathrm{~h}$, nonexopolysaccharide producers gave red colonies due to staining of the bacterial cell wall, while exopolysaccharide producers appeared as white colonies.

Quantification of exopolysaccharide: After the screening of EPS producing bacteria, EPS was obtained through precipitation using cold absolute ethanol (2:1) culture broth, then the precipitate was obtained by centrifugation at 5,000 rpm for $10 \mathrm{~min}$ and then concentration of EPS was measured by the phenol sulphuric acid method [23] using glucose as a standard solution and Optical Density was measured at 490 $\mathrm{nm}$.

Optimization of physicochemical parameters for exopolysaccharide production: Before using Response Surface Methodology (RSM) for optimization of parameters, preliminary studies with selected variables viz. carbon sources, nitrogen sources, $\mathrm{pH}$, temperature and incubation time were carried out by using One-Variable-at-a-Time (OVAT) method.

One variable at a time method: It depends on the change in one factor at a time while keeping all other factors constant [24]. All the experiments were carried out in triplicate and the average values were calculated.

Effect of different carbon sources: The carbon source used in standard production medium (Protease peptone (g) 10, Beef extract (g) 10, Yeast extract (g) 5, Glucose anhydrous (g) 20, Polysorbate 80 (mL) 1, Ammonium citrate (g) 2, Sodium acetate (g) 5, Magnesium sulfate heptahydrate (g) 0.01and Manganese sulfate monohydrate (g) 0.05, dipotassium hydrogen phosphate $(\mathrm{g}) 2$, Distilled water $(\mathrm{mL})$ $1000, \mathrm{pH} 6.5 \pm 0.2$ ) for exopolysaccharide production was replaced by other different carbon sources, viz. lactose, maltose, molasses, fructose and sucrose to check their effect on EPS production. The production medium with different carbon sources was inoculated with the organism and incubated at $37^{\circ} \mathrm{C}$ for $72 \mathrm{~h}$. After incubation, the EPS production was measured by phenol sulphuric acid method. Carbon source that yielded maximum EPS was further used in RSM studies to optimize its concentration in the medium.

Effect of different Nitrogen sources: The nitrogen source was replaced by other different nitrogen sources, viz. beef extract, peptone, yeast extract, urea, tryptophan, ammonium sulfate and ammonium nitrate to check their effect on EPS production, in the standard production medium. The production medium with different nitrogen sources was inoculated with the organism and incubated at $37^{\circ} \mathrm{C}$ for $72 \mathrm{~h}$. After this, the EPS production was measured by phenol sulphuric acid method. Nitrogen source that yielded maximum EPS was further used in RSM studies.

Effect of different temperatures: The standard production medium was inoculated with the organism and was incubated at different temperatures $\left(25^{\circ} \mathrm{C}, 30^{\circ} \mathrm{C}, 37^{\circ} \mathrm{C}\right.$ and $\left.45^{\circ} \mathrm{C}\right)$ for 72 $\mathrm{h}$ to check the effect of varying temperature on EPS production. After incubation, EPS production was measured and the temperature range that resulted in effective EPS was used for further studies.

Effect of different $\mathbf{p H}$ : The standard production medium with $\mathrm{pH}$ varying from 5 to 8 , was inoculated with THE organism and incubated at $37^{\circ} \mathrm{C}$ for $72 \mathrm{~h}$. After incubation, EPS production was measured and the $\mathrm{pH}$ range that gave effective EPS was further used for optimization by RSM.

Effect of incubation period: The standard production medium was inoculated with the organism and incubated for 24h, $48 \mathrm{~h}, 72 \mathrm{~h}$ and $96 \mathrm{~h}$ to check the effect of incubation time on EPS production. After incubation, EPS production was measured and the incubation period that resulted in effective EPS was used for further studies.

Response Surface Methodology: The chemically defined standard medium was first optimized by One Variable at a Time (OVAT) approach and the data was further used for the optimization by applying RSM of central composite design (CCD).

Experimental design: The levels of five independent variables, i.e., carbon source (A), nitrogen sources (B), $\mathrm{pH}$ (C), temperature (D) and incubation time (E), were optimized by RSM. The central composite design (CCD) with five factors at five levels was employed to investigate the first 
and higher order main effects of each factor and interactions amongst them. The five coded levels investigated in the current study were $(-2),(-1),(0),(+1)$ and $(+2)$. THE full experiment plan as per the experimental design, the minimum and maximum ranges of the variables with the coded and actual values given in the supplementary material (SM) TABLE I and II. The statistical software package "Design Expert巴" version 6.0 (Stat Ease, Inc, Minneapolis, USA) was used to generate polynomials and contour plots. All experiments were carried out in triplicates. For a FIVEFACTOR system, the following model equation was generated:

$\mathrm{Y}=\beta 0+\beta 1 \mathrm{~A}+\beta 2 \mathrm{~B}+\beta 3 \mathrm{C}+\beta 4 \mathrm{D}+\beta 5 \mathrm{E}+\beta 11 \mathrm{~A} 2+\beta 22 \mathrm{~B} 2+\beta 33 \mathrm{C} 2+\beta$ $44 \mathrm{D} 2+\beta 55 \mathrm{E} 2+\beta 12 \mathrm{AB}+\beta 13 \mathrm{AC}+\beta 14 \mathrm{AD}+\beta 15 \mathrm{AE}+\beta 23 \mathrm{BC}+\beta 2$ $4 \mathrm{BD}+\beta 25 \mathrm{BE}+\beta 34 \mathrm{CD}+\beta 35 \mathrm{CE}+\beta 45 \mathrm{DE}$

Where $Y$ was response variable, $\beta 0$ was intercept, $\beta 1, \beta 2, \beta 3$, $\beta 4, \beta 5$ were linear coefficients, $\beta 11, \beta 22, \beta 33, \beta 44$ and $\beta 55$ were quadratic coefficients, $\beta 12, \beta 13, \beta 14, \beta 15, \beta 23, \beta 24$, $\beta 25, \beta 34, \beta 35$ and $\beta 45$ were the second-order interaction coefficients and $\mathrm{A}, \mathrm{B}, \mathrm{C}, \mathrm{D}, \mathrm{A}^{2}, \mathrm{~B}^{2}, \mathrm{C}^{2}, \mathrm{D}^{2}, \mathrm{E} 2 \mathrm{AB}, \mathrm{AC}$, $\mathrm{AD}, \mathrm{AE}, \mathrm{BC}, \mathrm{BD}, \mathrm{BE}, \mathrm{CD}, \mathrm{CE}, \mathrm{DE}$ were level of independent variables.

Analysis of variance (ANOVA): A second-order polynomial equation was established based on the analysis of variance. The optimum ratio of the medium components was found using the Design-Expert 6.0 software optimization toolbox. Standard deviation, PRESS, $\mathrm{R}^{2}$ values were also analysed.

Model validation: The mathematical model generated during RSM implementation was validated by conducting checkpoint studies. The experimentally obtained data were compared with the predicted one, and the prediction error was calculated.

\section{RESULTS AND DISCUSSION}

Screening for exopolysaccharides production: Exopolysacccharides are thought to play an important role in protection against desiccation, toxic compounds, bacteriophages, osmotic stress, to permit adhesion to solid surface and biolfilm formation [25]. Some of bacterial EPSs can directly replace polysaccharides extracted from plants (e.g. guar gum or pectin) or algae (e.g. carrageenan or alginate) in traditional applications [26-27] because of their improved physical properties (e.g. xanthan gum or gellan gum). In addition, bacterial EPSs possess unique properties that can be helpful in launching a range of new commercial opportunities [28-29]. Several bacteria are reported to synthesize EPSs especially LAB such as Lactobacillus delbrueckii subsp. bulgaricus, Lactobacillus helveticus, Lactobacillus plantarum and Streptococcus themophilus [3031]. Therefore, available indigenous lactic acid bacterial isolates were screened for exopolysaccharide production on skim milk medium containing ruthenium red dye as an indicator, where the positive isolates gave white colonies whereas, the negative isolates gave red or pinkish colonies (Figure 1). This colour change may be attributed to the fact that ruthenium red dye is cationic in nature and it binds to anionic sites of cellular components present on the surface coat, thus imparting red colour to the bacterial cells. Whereas, EPS producing bacterial cells hinder this interaction, therefore, do not retain the colour of ruthenium red dye and produce white colonies on the screening medium [32]. Out of the total 11 isolates, 3 isolates i.e. AdF1 (Enterococcus faecium), AdF2 (Enterococcus faecium) and AdF3 (Enterococcus faecium) were found to be positive for EPS production whereas, 8 indigenous bacterial isolates were negative for this trait. In this study, Enterococcus faecium was found positive for exopolysaccharide production and this observation is also supported by Gardiner et al. [33], Giraffa [34], Mozzi et al. [35] and Kanmani et al. [36] who also reported the production of EPS by Enterococcus faecium.

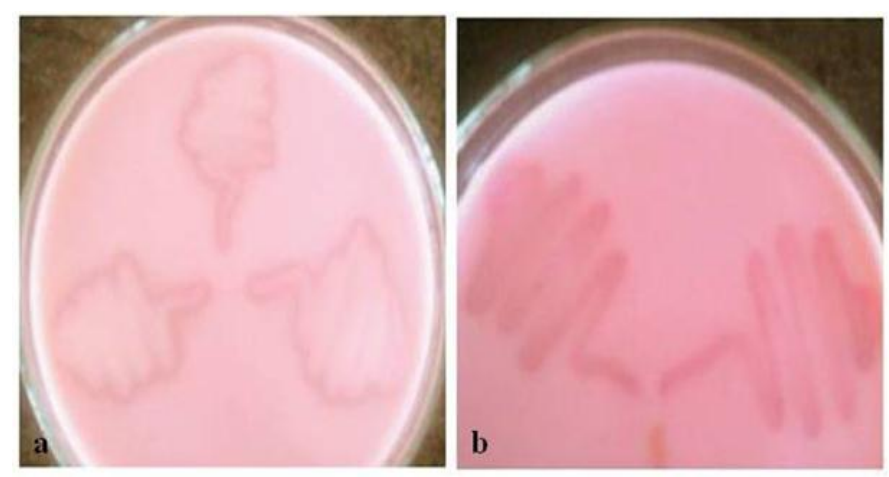

Figure 1 a) Exopolysaccharide producing isolates (white colonies) b) Non exolpolysaccharide producing isolates (red colonies)

Quantitative analysis: After qualitative analysis of the indigenous probiotic isolates, quantification of exopolysaccharides production was done at different intervals of time by using phenol sulphuric acid method [23], a method followed by other workers also [37-39]. For quantitative analysis, standard media was inoculated with three above referred bacterial isolates and exopolysaccharide production (24-96 h) was observed at different incubation time at $37^{\circ} \mathrm{C}$. The persual of data in SM Table III revealed that EPS production increased from $0.290 \mathrm{mg} / \mathrm{mL}$ to 0.712 $\mathrm{mg} / \mathrm{mL}$ at different incubation time and maximum production was seen at $72 \mathrm{~h}$ of incubation which is in concurrence with the findings of Ismail and Nampoothiri [40], Vijayabaskar et al. [41] and Abdulrazack et al. [39] who also reported maximum production at $72 \mathrm{~h}$. Among the different isolates, AdF3 produced maximum EPS (0.712 $\mathrm{mg} / \mathrm{mL})$ followed by AdF2 $(0.524 \mathrm{mg} / \mathrm{mL})$ and AdF1 $(0.427 \mathrm{mg} / \mathrm{mL})$. The strain level difference indicates that strain to strain variation in the production of 
exopolysaccharide exists in these isolates. Similar findings were observed by Peant et al. [42] regarding EPS production from different strains of Lactobacillus rhamnosus.

Optimization of parameters: Five parameters viz. carbon source, nitrogen source, $\mathrm{pH}$, temperature and incubation time were optimized for EPS production, by the approach of one variable at a time and then followed by Response Surface Methodology (RSM).

One variable at a time (OVAT) approach: Five parameters were optimized by OVAT approach for the production of EPS. In this approach, only single variable effect rather than the interaction of different parameters was observed.

Effect of different carbon sources: The structure of the exopolysaccharide is generally independent of the carbon substrate. However, choice of carbon substrate can influence both the quantity of exopolysaccharides produced as well as the extent of acylation of exopolysaccharides [43]. To examine the effect of different carbon sources on EPS production by three isolates, standard medium was supplemented with five carbon sources (2\% w/v) viz. lactose, maltose, molasses, fructose and sucrose (Table 1). Each organism utilized all the five carbon substrates for exopolysaccharide production, but maximum exopolysaccharide production i.e. $0.341,0.543$ and 0.751 $\mathrm{mg} / \mathrm{mL}$ was observed with lactose as a carbon source for AdF1, AdF2 and AdF3, respectively. These values are significantly higher than the production seen with other carbon sources. Many workers also reported the stimulatory effect of lactose on exopolysaccharide production from different organisms [44-46]. Since the maximum production is seen with lactose as the carbon source, it may be due to the fact that these isolates may be best adapted to utilize this substrate as a carbon source. This fact has been strengthened by the findings of Peiris et al. [44] who also observed highest EPS production in the presence of lactose by an organism isolated from milk.

Effect of different nitrogen sources: To examine the effect of different nitrogen sources $(2.7 \%$ w/v) beef extract, peptone, yeast extract, urea, tryptophan, ammonium sulfate and ammonium nitrate were used (Table 1). Each organism utilized all the seven nitrogen substrates for exopolysaccharide production but maximum exopolysaccharide production i.e. $0.402,0.426$ and 0.480 $\mathrm{mg} / \mathrm{mL}$ was observed with yeast extract as a nitrogen source for $A d F 1, A d F 2$ and AdF3, respectively. These values are significantly higher than the production seen with other nitrogen sources. Many workers also reported the stimulatory effect of yeast extract on exopolysaccharide production from different bacteria [39,46-47]. Exopolysaccharide producing microorganisms can utilize a variety of nitrogen sources and exopolysaccharide production is known to vary based upon the nitrogen substrates utilized [48]. Varying the nitrogen source has been shown to affect the molecular size of the exopolysaccharide formed [43]. Yeast extract is a complex substrate which contains carbohydrates, amino acids, peptides and water soluble which are excellent sources for the growth of microorganisms and thus for bacterial synthesized products [49]. Similar findings were also reported by Patil et al. [50], Habibi et al. [44] and Kanmani et al. [36], where yeast extracts have been shown to be better source of nitrogen than other sources for exopolysaccharide production.

\section{Table 1: Effect of different substrates on exopolysaccharide production}

Carbon sources Exopolysaccharide production $(\mathrm{mg} / \mathrm{mL})$

$\begin{array}{lccc} & \text { AdF1 } & \text { AdF2 } & \text { AdF3 } \\ \text { Lactose } & 0.341^{\mathrm{a}} & 0.543^{\mathrm{a}} & 0.751^{\mathrm{a}} \\ \text { Maltose } & 0.267^{\mathrm{e}} & 0.285^{\mathrm{e}} & 0.243^{\mathrm{e}} \\ \text { Molasses } & 0.281^{\mathrm{d}} & 0.311^{\mathrm{d}} & 0.340^{\mathrm{d}} \\ \text { Fructose } & 0.314^{\mathrm{c}} & 0.352^{\mathrm{c}} & 0.372^{\mathrm{c}} \\ \text { Sucrose } & 0.327^{\mathrm{b}} & 0.386^{\mathrm{b}} & 0.448^{\mathrm{b}}\end{array}$

Nitrogen sources

$\begin{array}{lccc}\text { Beef extract } & 0.290^{\mathrm{b}} & 0.302^{\mathrm{b}} & 0.317^{\mathrm{b}} \\ \text { Peptone } & 0.194^{\mathrm{d}} & 0.252^{\mathrm{d}} & 0.276^{\mathrm{d}} \\ \text { Yeast extract } & 0.402^{\mathrm{a}} & 0.426^{\mathrm{a}} & 0.450^{\mathrm{a}} \\ \text { Urea } & 0.147^{\mathrm{e}} & 0.175^{\mathrm{f}} & 0.186^{\mathrm{f}} \\ \text { Tryptophan } & 0.0 .86^{\mathrm{g}} & 0.132^{\mathrm{g}} & 0.141^{\mathrm{g}} \\ \text { Ammonium sulfate } 0.236^{\mathrm{c}} & 0.256^{\mathrm{c}} & 0.290^{\mathrm{c}} \\ \text { Ammonium nitrate } 0.131^{\mathrm{f}} & 0.182^{\mathrm{c}} & 0.196^{\mathrm{e}}\end{array}$

CD 5\%; 1. Organisms: S; 2. Treatments: 0.139748E-02; 3. Organisms and Treatments: 0.312486E-02. Each value represents mean of three replicates. In the same column, significant differences according to two-way ANOVA are indicated by different letters. Same letters represent that their values are statistically at par.

Effect of different pH: Just like all other living organisms, bacteria need appropriate physiological $\mathrm{pH}$ inside their cells. One way of affecting the growth and production of metabolites is by changing $\mathrm{pH}$ levels of the media. Bacteria prefer a certain $\mathrm{pH}$ balance so as to achieve maximum growth and to maintain beneficial traits such as production of metabolites [51-52]. It also plays an important role in inducing morphological changes in microbes and in secretion 
of enzymes [53]. Standard media with varying $\mathrm{pH}$ (5-8) were inoculated with organisms and incubated for $72 \mathrm{~h}$ at $37^{\circ} \mathrm{C}$. Similar pH range was also used by Duta et al. [54] and Sivakumar et al. [55] to study exopolysaccharide production from bacterial isolates. Data presented in Table 2 depict the effect of varying $\mathrm{pH}$ on exopolysaccharide production. The highest exopolysaccharide production was observed at $\mathrm{pH}$ 7.0, i.e. $0.421,0.492$ and $0.531 \mathrm{mg} / \mathrm{mL}$ for AdF1 (Enterococcus faecium), AdF2 (E. faecium) and AdF3 (E. faecium), respectively which is significantly higher than production at other $\mathrm{pH}$ values. Minimum exopolysaccharide production was obtained at $\mathrm{pH} 5.0 \mathrm{pH}$ is known to be an important factor that influences the growth and EPS production of bacterial isolates [56]. Besides the cultural conditions of the medium, the properties of the EPS produced are also known to vary with varying $\mathrm{pH}$ [57]. Other workers also reported maximum EPS production at $\mathrm{pH} 7$ from different bacteria $[41,44]$.

Effect of different temperatures: It is well known that microbes are more tolerant to environmental conditions than other organisms. However, each species has its own characteristics and particular range of temperature in which it grows and reproduces best. For this, standard media were inoculated with three isolates at different temperatures i.e. $25^{\circ} \mathrm{C}, 30^{\circ} \mathrm{C}, 37^{\circ} \mathrm{C}$ and $45^{\circ} \mathrm{C}$ for $72 \mathrm{~h}$. Same temperature range was also used by Habibi et al. [44] and Zhang et al. [58] for examining the exopolysaccharide production. Data presented in Table 2 depict the effect of different temperatures on EPS production. The highest EPS production was observed at $37^{\circ} \mathrm{C}$ i.e. $0.427,0.524$ and $0.712 \mathrm{mg} / \mathrm{mL}$ for $\mathrm{AdF} 1$ (Enterococcus faecium), AdF2 (E. faecium) and AdF3 (E. faecium), respectively which is significantly higher than the production seen at other temperatures. These results are in concurrence with the findings of exopolysaccharide production by Vijayabaskar et al. [41] who also observed highest production of EPS at $37^{\circ} \mathrm{C}$ from different bacteria. Beyond the temperature $37^{\circ} \mathrm{C}$ the production declined drastically which may be due to the reason that these organisms are mesophillic in nature and may not be in a position to produce secondary metabolites at the same rate at which they produced at $37^{\circ} \mathrm{C}$.

Effect of different incubation time: The growth of a bacterial culture is one of the most familiar examples of important dynamical processes in ecology. Incubation period plays an important role in defining the production of particular metabolite e.g. secondary metabolites are produced at stationary phase and the culture must be incubated for that much duration of time for detection of that particular metabolite. Standard media were inoculated with probiotic isolates incubated at $37^{\circ} \mathrm{C}$ for 24 to $96 \mathrm{~h}$ and their exopolysaccharide production was determined. Data presented in Table 2 reveal that maximum exopolysaccharide production by all the isolates was obtained after $72 \mathrm{~h}$ of incubation which is in concurrence with the findings of other workers [39-41] who also reported maximum production at $72 \mathrm{~h}$. Among the different isolates, AdF3 produced maximum EPS $(0.712 \mathrm{mg} / \mathrm{mL})$ followed by AdF2 (0.524 $\mathrm{mg} / \mathrm{mL})$ and AdF1 $(0.427 \mathrm{mg} / \mathrm{mL})$. Different level of production by different strains of the same organisms has been reported earlier also by Peant et al. [42].

\section{Table 2: Effect of physical parameters on exopolysaccharide production}

\begin{tabular}{lccc} 
pH & \multicolumn{3}{c}{ Exopolysaccharide production $(\mathbf{m g} / \mathbf{m L})$} \\
& AdF1 & AdF2 & AdF3 \\
$\mathbf{5}$ & $0.270^{\mathrm{d}}$ & $0.317^{\mathrm{d}}$ & $0.332^{\mathrm{d}}$ \\
$\mathbf{6}$ & $0.405^{\mathrm{b}}$ & $0.460^{\mathrm{b}}$ & $0.525^{\mathrm{b}}$ \\
$\mathbf{7}$ & $0.421^{\mathrm{a}}$ & $0.492^{\mathrm{a}}$ & $0.531^{\mathrm{a}}$ \\
$\mathbf{8}$ & $0.317^{\mathrm{c}}$ & $0.385^{\mathrm{c}}$ & $0.448^{\mathrm{c}}$
\end{tabular}

Temperature $\left({ }^{\circ} \mathbf{C}\right)$

$\begin{array}{llll}25 & 0.250^{\mathrm{c}} & 0.410^{\mathrm{b}} & 0.434^{\mathrm{b}} \\ 30 & 0.312^{\mathrm{b}} & 0.374^{\mathrm{c}} & 0.420^{\mathrm{c}} \\ 37 & 0.427^{\mathrm{a}} & 0.524^{\mathrm{a}} & 0.712^{\mathrm{a}} \\ 45 & 0.189^{\mathrm{d}} & 0.247^{\mathrm{d}} & 0.287^{\mathrm{d}}\end{array}$

Incubation time (h)

$\begin{array}{cccc}24 & \text { ND } & \text { ND } & \text { ND } \\ 48 & 0.290^{\mathrm{c}} & 0.403^{\mathrm{c}} & 0.651^{\mathrm{c}} \\ 72 & 0.427^{\mathrm{a}} & 0.524^{\mathrm{a}} & 0.712^{\mathrm{a}} \\ 96 & 0.316^{\mathrm{b}} & 0.460^{\mathrm{b}} & 0.665^{\mathrm{b}}\end{array}$

CD 5\%; 1. Organisms: S; 2. Treatments: 0.139748E-02; 3. Organisms and Treatments: 0.312486E-02, ND: Not Determined.

Each value represents mean of three replicates. In the same column, significant differences according to two-way ANOVA are indicated by different letters. Same letters represent that their values are statistically at par.

Response Surface Methodology: Response Surface Methodology (RSM) was used for further optimization study. The RSM was mainly used to find out the optima of the variables for which the response was maximized [59]. Response Surface Methodology used in this investigation suggested the importance of various factors at different levels. A high similarity was observed between the predicted and experimental results, which reflected the accuracy and applicability of RSM to optimize the process for 
exopolysaccharide production. The exopolysaccharide yield attained was higher than that at concentrations considered to be optimal by 'One Variable at a Time' approach. These observations suggested that the concentrations of the variables considered to be optimum by 'one variable at a time' approach were actually lesser than those actually required for maximum exopolysaccharide production. Liu et al. [45] optimized the exopolysaccharide production of Berkleasmium sp. Dzfs12 by using Response Surface Methodology and reported the effectiveness and reliability of the empirical models obtained. Qiang et al. [60] also used RSM to optimize fermentation conditions for exopolysaccharide production, by Klebsiella sp. H-207.

Experimental design: Second-order experimental design, i.e. Central Composite Design (CCD) with five factors at five levels was employed to investigate the first- and higher-order effects of each factor and interactions among them. The five coded levels investigated in the current study were $-2,-1,0$, +1 and +2 . The full experiment plan as per the experimental design and the minimum and the maximum range of the variables with the coded and actual values along with the experimental and predicted values for AdF1, AdF2 and AdF3 are given in Table 3,4 and 5, respectively. The statistical software package Design Expert ${ }^{\circledR}$ version 6.0 (Stat Ease, Inc, Minneapolis, USA) was used to generate polynomials and the response surface plots (three dimensional plots and interaction graphs). All experiments were carried out in triplicates. For a five factor system, the following model equation was generated:

$\mathrm{Y}=\beta 0+\beta 1 \mathrm{~A}+\beta 2 \mathrm{~B}+\beta 3 \mathrm{C}+\beta 4 \mathrm{D}+\beta 5 \mathrm{E}+\beta 11 \mathrm{~A} 2+\beta 22 \mathrm{~B} 2+\beta 33 \mathrm{C} 2+\beta$ $44 \mathrm{D} 2+\beta 55 \mathrm{E} 2+\beta 12 \mathrm{AB}+\beta 13 \mathrm{AC}+\beta 14 \mathrm{AD}+\beta 15 \mathrm{AE}+\beta 23 \mathrm{BC}+\beta 2$ $4 \mathrm{BD}+\beta 25 \mathrm{BE}+\beta 34 \mathrm{CD}+\beta 35 \mathrm{CE}+\beta 45 \mathrm{DE}$

Where $Y$ was response variable, $\beta 0$ was intercept, $\beta 1, \beta 2, \beta 3$, $\beta 4, \beta 5$ were linear coefficients, $\beta 11, \beta 22, \beta 33, \beta 44$ and $\beta 55$ were quadratic coefficients, $\beta 12, \beta 13, \beta 14, \beta 15, \beta 23, \beta 24$, $\beta 25, \beta 34, \beta 35$ and $\beta 45$ were the second-order interaction coefficients and $\mathrm{A}, \mathrm{B}, \mathrm{C}, \mathrm{D}, \mathrm{A}^{2}, \mathrm{~B}^{2}, \mathrm{C}^{2}, \mathrm{D}^{2}$, E2 AB, AC, AD, $\mathrm{AE}, \mathrm{BC}, \mathrm{BD}, \mathrm{BE}, \mathrm{CD}, \mathrm{CE}, \mathrm{DE}$ were the levels of independent variables.

\section{Results of AdF1 from CCD of RSM}

For five factor system, model equation generated for AdF1 was:

Response $(\mathrm{mg} / \mathrm{mL})=+0.73+9.211 \mathrm{E}-00 * \mathrm{~A}+0.031 * \mathrm{~B}+0.032$ $* \mathrm{C}+0.013 * \mathrm{D}+0.079 * \mathrm{E}-6.786 \mathrm{E}-003 * \mathrm{~A} 2+3.998 \mathrm{E}-003 *$ $\mathrm{B} 2-0.13 * \mathrm{C} 2-0.097 * \mathrm{D} 2-0.035 * \mathrm{E} 2+3.469 \mathrm{E}-003 * \mathrm{~A} * \mathrm{~B}$ +2.594 E-003*A*C +3.656 E-003 *A*D +7.187 E-004 $* \mathrm{~A} * \mathrm{E}-4.844 \mathrm{E}-003 * \mathrm{~B} * \mathrm{C}-4.063 \mathrm{E}-004 * \mathrm{~B} * \mathrm{D}-4.219 \mathrm{E}-003$ $* \mathrm{~B} * \mathrm{E}+0.017 * \mathrm{C} * \mathrm{D}+1.562$ E-004 *C*E +9.219 E-003 $* \mathrm{D} * \mathrm{E}$

Central values for independent variables for AdF1 (Enterococcus faecium) (Table 3) were obtained at $6 \%(\mathrm{w} / \mathrm{v})$, $13.82 \%(\mathrm{w} / \mathrm{v}), 6.75,36.5^{\circ} \mathrm{C}$ and $60 \mathrm{~h}$ for carbon source (lactose), nitrogen source (yeast extract), $\mathrm{pH}$, temperature and incubation period, respectively where, maximum response (Y) $0.864 \mathrm{mg} / \mathrm{mL}$ was achieved. According to CCD of RSM, B, C, E, C2, D2, E2 were significant model terms. Interactions of other factors were also found equally important for EPS production. The response surface curves were plotted for the variation in EPS production, as function of concentration of two variables when all the other factors were kept at their ' $\mathrm{O}$ ' (central) levels. The three-dimensional counter plots (Figure $2 \mathrm{a}, \mathrm{b}, \mathrm{c}$ and d) clearly show that interactions between carbon \& nitrogen, temperature \& incubation period, $\mathrm{pH} \&$ temperature, $\mathrm{pH} \&$ time have direct effect on EPS production of AdF1. Interactions of other factors were also found equally important for EPS production. These experimental findings are in close agreement with the model predictions.

Table 3: Experimental design and results of AdF1 from CCD of RSM

\begin{tabular}{|c|c|c|c|c|c|c|c|}
\hline $\begin{array}{c}\text { Experime } \\
\mathrm{nt}\end{array}$ & $\begin{array}{l}\text { Carbo } \\
\mathrm{n}(\%)\end{array}$ & $\begin{array}{l}\text { Nitroge } \\
\mathrm{n}(\%)\end{array}$ & $\mathrm{pH}$ & $\begin{array}{l}\text { Temperature }\left(^{\circ}\right. \\
\text { C) }\end{array}$ & $\begin{array}{c}\text { Incubatio } \\
\text { n period } \\
\text { (h) }\end{array}$ & $\begin{array}{c}\text { Actual } \\
\text { values(* } \\
\text { Y) (EPS } \\
\text { productio } \\
\text { n mg/mL) }\end{array}$ & $\begin{array}{c}\text { Predicted } \\
\text { values } \\
\text { (EPS } \\
\text { productio } \\
\mathrm{n} \\
\mathrm{mg} / \mathrm{mL} \text { ) }\end{array}$ \\
\hline 1 & 2.0 & 2.0 & 5 & 28 & 48 & 0.246 & 0.32 \\
\hline 2 & 10.0 & 2.0 & 5 & 28 & 48 & 0.257 & 0.32 \\
\hline 3 & 2.0 & 9.0 & 5 & 28 & 48 & 0.364 & 0.40 \\
\hline 4 & 10.0 & 9.0 & 5 & 28 & 48 & 0.378 & 0.41 \\
\hline 5 & 2.0 & 2.0 & 8.5 & 28 & 48 & 0.316 & 0.36 \\
\hline 6 & 10.0 & 2.0 & 8.5 & 28 & 48 & 0.349 & 0.37 \\
\hline 7 & 2.0 & 9.0 & 8.5 & 28 & 48 & 0.367 & 0.41 \\
\hline 8 & 10.0 & 9.0 & 8.5 & 28 & 48 & 0.377 & 0.43 \\
\hline 9 & 2.0 & 2.0 & 5 & 45 & 48 & 0.264 & 0.29 \\
\hline 10 & 10.0 & 2.0 & 5 & 45 & 48 & 0.289 & 0.30 \\
\hline 11 & 2.0 & 9.0 & 5 & 45 & 48 & 0.319 & 0.36 \\
\hline 12 & 10.0 & 9.0 & 5 & 45 & 48 & 0.339 & 0.39 \\
\hline 13 & 2.0 & 2.0 & 8.5 & 45 & 48 & 0.409 & 0.39 \\
\hline 14 & 10.0 & 2.0 & 8.5 & 45 & 48 & 0.416 & 0.42 \\
\hline 15 & 2.0 & 9.0 & 8.5 & 45 & 48 & 0.436 & 0.45 \\
\hline 16 & 10.0 & 9.0 & 8.5 & 45 & 48 & 0.479 & 0.48 \\
\hline 17 & 2.0 & 2.0 & 5 & 28 & 72 & 0.481 & 0.47 \\
\hline 18 & 10.0 & 2.0 & 5 & 28 & 72 & 0.463 & 0.47 \\
\hline 19 & 2.0 & 9.0 & 5 & 28 & 72 & 0.492 & 0.53 \\
\hline 20 & 10.0 & 9.0 & 5 & 28 & 72 & 0.501 & 0.54 \\
\hline 21 & 2.0 & 2.0 & 8.5 & 28 & 72 & 0.526 & 0.50 \\
\hline 22 & 10.0 & 2.0 & 8.5 & 28 & 72 & 0.532 & 0.52 \\
\hline 23 & 2.0 & 9.0 & 8.5 & 28 & 72 & 0.546 & 0.54 \\
\hline 24 & 10.0 & 9.0 & 8.5 & 45 & 72 & 0.597 & 0.57 \\
\hline 25 & 2.0 & 2.0 & 5 & 45 & 72 & 0.492 & 0.47 \\
\hline 26 & 10.0 & 2.0 & 5 & 45 & 72 & 0.517 & 0.49 \\
\hline 27 & 2.0 & 9.0 & 5 & 45 & 72 & 0.546 & 0.53 \\
\hline 28 & 10.0 & 9.0 & 5 & 45 & 72 & 0.593 & 0.56 \\
\hline 29 & 2.0 & 2.0 & 8.5 & 45 & 72 & 0.602 & 0.58 \\
\hline 30 & 10.0 & 2.0 & 8.5 & 45 & 72 & 0.632 & 0.60 \\
\hline 31 & 2.0 & 9.0 & 8.5 & 45 & 72 & 0.656 & 0.61 \\
\hline 32 & 10.0 & 9.0 & 8.5 & 45 & 72 & 0.692 & 0.65 \\
\hline 33 & -3.51 & 5.50 & 6.75 & 36.5 & 60 & 0.701 & 0.67 \\
\hline 34 & 15.51 & 5.50 & 6.75 & 36.5 & 60 & 0.722 & 0.71 \\
\hline 35 & 6.0 & -2.82 & 6.75 & 36.5 & 60 & 0.681 & 0.68 \\
\hline 36 & 6.0 & 13.82 & 6.75 & 36.5 & 60 & 0.864 & 0.82 \\
\hline 37 & 6.0 & 5.50 & 2.59 & 36.5 & 60 & 0.0 & 0 \\
\hline $\begin{array}{l}38 \\
39\end{array}$ & 6.0 & 5.50 & 10.91 & $\begin{array}{c}36.5 \\
16.28\end{array}$ & $\begin{array}{l}60 \\
60\end{array}$ & $\begin{array}{c}0.0 \\
0.264\end{array}$ & $\begin{array}{c}0.054 \\
0.14\end{array}$ \\
\hline $\begin{array}{l}39 \\
40\end{array}$ & $\begin{array}{l}6.0 \\
6.0\end{array}$ & $\begin{array}{l}5.50 \\
5.50\end{array}$ & $\begin{array}{l}6.75 \\
6.75\end{array}$ & $\begin{array}{l}16.28 \\
56.72\end{array}$ & 60 & $\begin{array}{l}0.264 \\
0.133\end{array}$ & $\begin{array}{l}0.14 \\
0.21\end{array}$ \\
\hline 41 & 6.0 & 5.50 & 6.75 & 36.5 & 31.46 & 0.522 & 0.34 \\
\hline 42 & 6.0 & 5.50 & $\begin{array}{l}6.75 \\
675\end{array}$ & 36.5 & 88.54 & 0.584 & 0.72 \\
\hline 43 & 6.0 & 5.50 & 6.75 & 36.5 & 60 & 0.764 & 0.73 \\
\hline 44 & 6.0 & 5.50 & 6.75 & 36.5 & 60 & 0.681 & 0.73 \\
\hline 45 & 6.0 & 5.50 & 6.75 & 36.5 & 60 & 0.77 & 0.73 \\
\hline 46 & 6.0 & 5.50 & 6.75 & 36.5 & 60 & 0.652 & 0.73 \\
\hline 47 & 6.0 & 5.50 & 6.75 & 36.5 & 60 & 0.692 & 0.73 \\
\hline 48 & 6.0 & 5.50 & 6.75 & 36.5 & 60 & 0.764 & 0.73 \\
\hline 49 & 6.0 & 5.50 & 6.75 & 36.5 & 60 & 0.764 & 0.73 \\
\hline 50 & 6.0 & 5.50 & 6.75 & 36.5 & 60 & 0.764 & 0.73 \\
\hline
\end{tabular}

*The response Y was the mean value of these experiments 


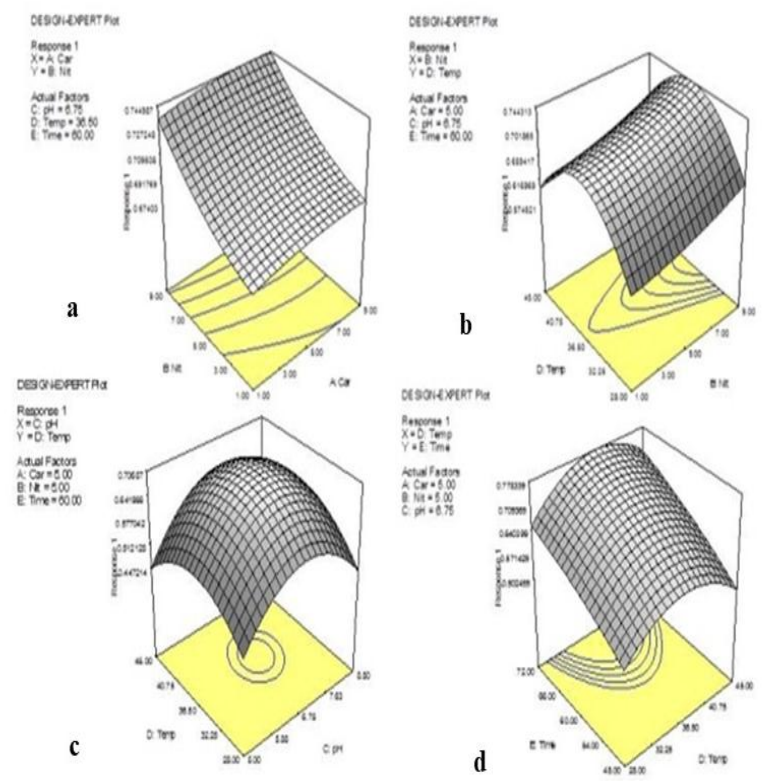

Figure 2: Three-dimensional response surface curves for exopolysaccharide production plotted between (a) Lactose $(\% \mathrm{w} / \mathrm{v})$ and Yeast Extract (\% w/v) (b) Temperature and Incubation time (c) temperature and $\mathrm{pH}(\mathrm{d}) \mathrm{pH}$ and time

\section{Results of AdF2 from CCD of RSM}

For five factor system, model equation generated for AdF2 was:

Response $(\mathrm{mg} / \mathrm{mL})=+0.70+5.162 \mathrm{E}-$

$003 * \mathrm{~A}+0.030 * \mathrm{~B}+0.030 * \mathrm{C}+0.015 * \mathrm{D}+0.088 * \mathrm{E}-3.803 \mathrm{E}$

$003 * \mathrm{~A} 2+9.279 \mathrm{E}-003 * \mathrm{~B} 2-0.13 * \mathrm{C} 2-0.094 * \mathrm{D} 2-0.016 * \mathrm{E} 2-$

$6.875 \mathrm{E}-004 * \mathrm{~A} * \mathrm{~B}-1.500 \mathrm{E} 003 * \mathrm{~A} * \mathrm{C}+8.062 \mathrm{E}-003 * \mathrm{~A} * \mathrm{D}-$

4.875E-003*A*E-5.813E-003*B*C+5.000E-004*B*D-

$6.688 \mathrm{E}-003 * \mathrm{~B} * \mathrm{E}+0.018 * \mathrm{C} * \mathrm{D}-2.500 \mathrm{E}-003 * \mathrm{C} * \mathrm{E}+0.012 * \mathrm{D} * \mathrm{E}$

In case of AdF2 the central values for independent variables (Table 4) were obtained at 5\% (w/v), 14.51\% (w/v), 6.75, $36.5^{\circ} \mathrm{C}$ and $60 \mathrm{~h}$ for carbon source (lactose), nitrogen source (yeast extract), $\mathrm{pH}$, temperature and incubation period, respectively where, maximum response (Y) $0.893 \mathrm{mg} / \mathrm{mL}$ was achieved. According to CCD of RSM, B, C, E, C2, D2 are significant model terms. The three dimentional counter plots (Figure 3 a, b, c and d) shows that interactions between carbon source \& nitrogen source; temperature \& nitrogen source; temperature \& $\mathrm{pH}$; temperature \& incubation time have better effect on the exopolysaccharide production of AdF2.
Table 4: Experimental design and results of AdF2 from CCD of RSM

\begin{tabular}{|c|c|c|c|c|c|c|c|}
\hline $\begin{array}{l}\text { Experiment } \\
\mathrm{s}\end{array}$ & $\begin{array}{l}\text { Carbo } \\
\mathrm{n} \\
\text { source } \\
(\%)\end{array}$ & $\begin{array}{l}\text { Nitroge } \\
\mathrm{n} \\
\text { source } \\
(\%)\end{array}$ & $\mathrm{pH}$ & $\begin{array}{l}\text { Temperatur } \\
\mathrm{e} \\
\left({ }^{0} \mathrm{C}\right)\end{array}$ & $\begin{array}{l}\text { Incubatio } \\
\text { n period } \\
\text { (h) }\end{array}$ & $\begin{array}{l}\text { Experiment } \\
\quad \text { al value } \\
\quad(* Y) \\
\text { (EPS } \\
\text { production } \\
\mathrm{mg} / \mathrm{mL} \text { ) }\end{array}$ & $\begin{array}{l}\text { Predicted } \\
\text { value(EP } \\
\mathrm{S} \\
\text { productio } \\
\mathrm{n} \\
\mathrm{mg} / \mathrm{mL})\end{array}$ \\
\hline 1 & 1 & 1 & 5 & 28 & 48 & 0.251 & 0.32 \\
\hline 2 & 9 & 1 & 5 & 28 & 48 & 0.262 & 0.32 \\
\hline 3 & 1 & 9 & 5 & 28 & 48 & 0.369 & 0.40 \\
\hline 4 & 9 & 9 & 5 & 28 & 48 & 0.384 & 0.41 \\
\hline 5 & 1 & 1 & 8.5 & 28 & 48 & 0.321 & 0.36 \\
\hline 6 & 9 & 1 & 8.5 & 28 & 48 & 0.355 & 0.36 \\
\hline 7 & 1 & 9 & 8.5 & 28 & 48 & 0.373 & 0.42 \\
\hline 8 & 9 & 9 & 8.5 & 28 & 48 & 0.383 & 0.42 \\
\hline 9 & 1 & 1 & 5 & 45 & 48 & 0.27 & 0.27 \\
\hline 10 & 9 & 1 & 5 & 45 & 48 & 0.296 & 0.31 \\
\hline 11 & 1 & 9 & 5 & 45 & 48 & 0.326 & 0.36 \\
\hline 12 & 9 & 9 & 5 & 45 & 48 & 0.345 & 0.40 \\
\hline 13 & 1 & 1 & 8.5 & 45 & 48 & 0.415 & 0.39 \\
\hline 14 & 9 & 1 & 8.5 & 45 & 48 & 0.422 & 0.42 \\
\hline 15 & 1 & 9 & 8.5 & 45 & 48 & 0.441 & 0.45 \\
\hline 16 & 9 & 9 & 8.5 & 45 & 48 & 0.485 & 0.48 \\
\hline 17 & 1 & 1 & 5 & 28 & 72 & 0.487 & 0.50 \\
\hline 18 & 9 & 1 & 5 & 28 & 72 & 0.47 & 0.49 \\
\hline 19 & 1 & 9 & 5 & 28 & 72 & 0.499 & 0.56 \\
\hline 20 & 9 & 9 & 5 & 28 & 72 & 0.506 & 0.54 \\
\hline 21 & 1 & 1 & 8.5 & 28 & 72 & 0.531 & 0.53 \\
\hline 22 & 9 & 1 & 8.5 & 28 & 72 & 0.537 & 0.51 \\
\hline 23 & 1 & 9 & 8.5 & 28 & 72 & 0.603 & 0.57 \\
\hline 24 & 9 & 9 & 8.5 & 28 & 72 & 0.496 & 0.55 \\
\hline 25 & 1 & 1 & 5 & 45 & 72 & 0.522 & 0.50 \\
\hline 26 & 9 & 1 & 5 & 45 & 72 & 0.523 & 0.52 \\
\hline 27 & 1 & 9 & 5 & 45 & 72 & 0.551 & 0.56 \\
\hline 28 & 9 & 9 & 5 & 45 & 72 & 0.601 & 0.58 \\
\hline 29 & 1 & 1 & 8.5 & 45 & 72 & 0.607 & 0.60 \\
\hline 30 & 9 & 1 & 8.5 & 45 & 72 & 0.638 & 0.62 \\
\hline 31 & 1 & 9 & 8.5 & 45 & 72 & 0.66 & 0.64 \\
\hline 32 & 9 & 9 & 8.5 & 45 & 72 & 0.699 & 0.65 \\
\hline 33 & 0 & 5 & 6.75 & 36.5 & 60 & 0.707 & 0.67 \\
\hline 34 & 14.51 & 5 & 6.75 & 36.5 & 60 & 0.727 & 0.70 \\
\hline 35 & 5 & 0 & 6.75 & 36.5 & 60 & 0.689 & 0.69 \\
\hline 36 & 5 & 14.51 & 6.75 & 36.5 & 60 & 0.893 & 0.83 \\
\hline 37 & 5 & 5 & 2.59 & 36.5 & 60 & 0 & 0 \\
\hline 38 & 5 & 5 & 10.21 & 36.5 & 60 & 0 & 0.037 \\
\hline 39 & 5 & 5 & 6.75 & 16.28 & 60 & 0.27 & 0.13 \\
\hline 40 & 5 & 5 & 6.75 & 56.72 & 60 & 0.14 & 0.21 \\
\hline 41 & 5 & 5 & 6.75 & 36.5 & 31.46 & 0.527 & 0.41 \\
\hline 42 & 5 & 5 & 6.75 & 36.5 & 88.54 & 0.771 & 0.82 \\
\hline 43 & 5 & 5 & 6.75 & 36.5 & 60 & 0.689 & 0.70 \\
\hline 44 & 5 & 5 & 6.75 & 36.5 & 60 & 0.77 & 0.70 \\
\hline 45 & 5 & 5 & 6.75 & 36.5 & 60 & 0.689 & 0.70 \\
\hline 46 & 5 & 5 & 6.75 & 36.5 & 60 & 0.776 & 0.70 \\
\hline 47 & 5 & 5 & 6.75 & 36.5 & 60 & 0.557 & 0.70 \\
\hline 48 & 5 & 5 & 6.75 & 36.5 & 60 & 0.697 & 0.70 \\
\hline 49 & 5 & 5 & 6.75 & 36.5 & 60 & 0.751 & 0.70 \\
\hline 50 & 5 & 5 & 6.75 & 36.5 & 60 & 0.751 & 0.70 \\
\hline
\end{tabular}

\footnotetext{
* The response $\mathrm{Y}$ was the mean value of these experiments
} 

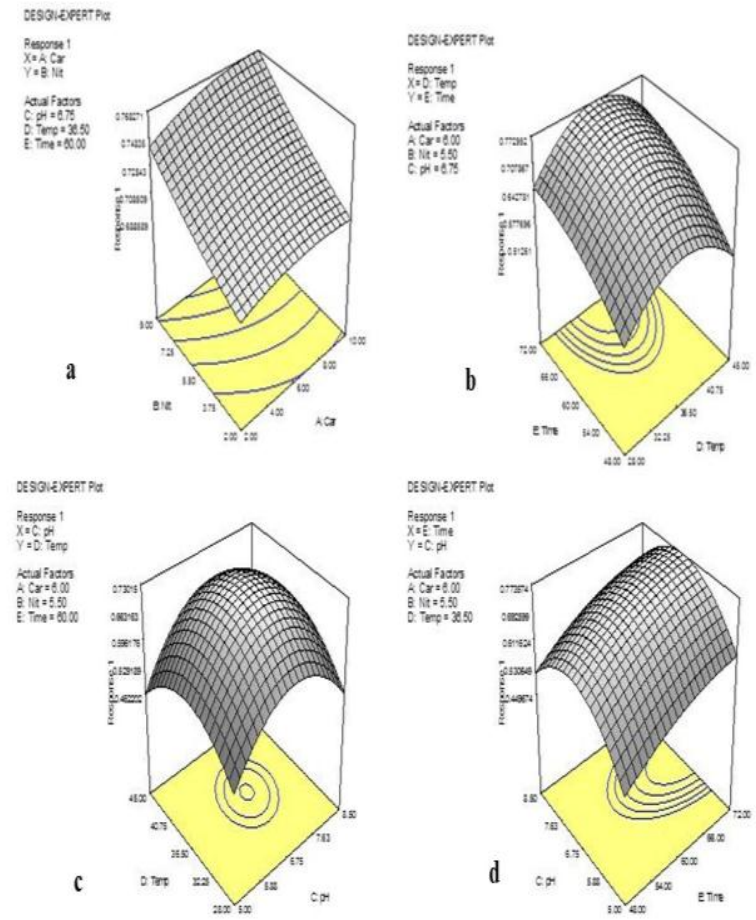

Figure 3: Three dimensional response surface curves for exopolysaccharide production plotted between (a) Lactose (\% w/v) and Yeast Extract (\% w/v) (b) Temperature and nitrogen source (c) temperature and $\mathrm{pH}(\mathrm{d})$ temperature and incubation time

\section{Results of AdF3 form CCD of RSM}

For five factor system, model equation generated for AdF3 was:

Response $(\mathrm{mg} / \mathrm{mL})=+0.72+5.472 \mathrm{E} 003 * \mathrm{~A}+0.035 * \mathrm{~B}+0.022 * \mathrm{C}$ $+0.024 * \mathrm{D}+0.079 * \mathrm{E}+3.000 \mathrm{E}-003 * \mathrm{~A} 2+0.027 * \mathrm{~B} 2-0.13 * \mathrm{C} 2-$ $0.091 * \mathrm{D} 2-0.046 * \mathrm{E} 22.344 \mathrm{E} 003 * \mathrm{~A} * \mathrm{~B}+8.156 \mathrm{E}-003 * \mathrm{~A} * \mathrm{C}-$

$2.156 \mathrm{E}-003 * \mathrm{~A} * \mathrm{D}-5.156 \mathrm{E}-003 * \mathrm{~A} * \mathrm{E}-6.563 \mathrm{E}-004 * \mathrm{~B} * \mathrm{C}-$

4.469E-003*B*D-8.094E-003*B*E+5.656E-003*C*D-

$0.012 * \mathrm{C} * \mathrm{E}+0.021 * \mathrm{D} * \mathrm{E}$

In case of AdF3 central values for independent variables (Table 5) for were obtained at 5\% (w/v), 14.51\% (w/v), 6.75, $36.5^{\circ} \mathrm{C}$ and $60 \mathrm{~h}$ for carbon source (lactose), nitrogen source (yeast extract), $\mathrm{pH}$, temperature and incubation period, respectively where, maximum response (Y) $1.051 \mathrm{mg} / \mathrm{mL}$ was achieved. According to CCD of RSM, B, E, C2, D2, E2 are significant model terms. The three-dimensional counter plots (Figure $4 \mathrm{a}, \mathrm{b}, \mathrm{c}$ and d) shows interactions between carbon source \& nitrogen source; $\mathrm{pH} \&$ nitrogen source; temperature \& $\mathrm{pH}$; temperature \& incubation time, have direct effect on EPS production of AdF3.

Table 5: Experimental design and results of AdF3 from CCD of RSM

\begin{tabular}{|c|c|c|c|c|c|c|c|}
\hline $\begin{array}{l}\text { Experiment } \\
\mathrm{s}\end{array}$ & $\begin{array}{l}\text { Carbo } \\
\mathrm{n} \\
\text { source } \\
(\%)\end{array}$ & $\begin{array}{l}\text { Nitroge } \\
\mathrm{n} \\
\text { source } \\
(\%)\end{array}$ & $\mathrm{pH}$ & $\begin{array}{l}\text { Temperatur } \\
\quad \mathrm{e} \\
\left({ }^{0} \mathrm{C}\right)\end{array}$ & $\begin{array}{l}\text { Incubatio } \\
\text { n period } \\
\text { (h) }\end{array}$ & $\begin{array}{l}\text { Experiment } \\
\quad \text { al value } \\
\quad(* Y) \\
\text { (EPS } \\
\text { production } \\
\mathrm{mg} / \mathrm{mL})\end{array}$ & $\begin{array}{l}\text { Predicted } \\
\text { value(EP } \\
\mathrm{S} \\
\text { productio } \\
\mathrm{n} \\
\mathrm{mg} / \mathrm{mL})\end{array}$ \\
\hline 1 & 1 & 1 & 5 & 28 & 48 & 0.259 & 0.32 \\
\hline 2 & 9 & 1 & 5 & 28 & 48 & 0.272 & 0.33 \\
\hline 3 & 1 & 9 & 5 & 28 & 48 & 0.378 & 0.42 \\
\hline 4 & 9 & 9 & 5 & 28 & 48 & 0.386 & 0.36 \\
\hline 5 & 1 & 1 & 8.5 & 28 & 48 & 0.327 & 0.41 \\
\hline 6 & 9 & 1 & 8.5 & 28 & 48 & 0.356 & 0.46 \\
\hline 7 & 1 & 9 & 8.5 & 28 & 48 & 0.372 & 0.50 \\
\hline 8 & 9 & 9 & 8.5 & 28 & 48 & 0.382 & 0.33 \\
\hline 9 & 1 & 1 & 5 & 45 & 48 & 0.279 & 0.33 \\
\hline 10 & 9 & 1 & 5 & 45 & 48 & 0.305 & 0.41 \\
\hline 11 & 1 & 9 & 5 & 45 & 48 & 0.333 & 0.41 \\
\hline 12 & 9 & 9 & 5 & 45 & 48 & 0.359 & 0.39 \\
\hline 13 & 1 & 1 & 8.5 & 45 & 48 & 0.429 & 0.43 \\
\hline 14 & 9 & 1 & 8.5 & 45 & 48 & 0.434 & 0.47 \\
\hline 15 & 1 & 9 & 8.5 & 45 & 48 & 0.451 & 0.50 \\
\hline 16 & 9 & 9 & 8.5 & 45 & 48 & 0.491 & 0.48 \\
\hline 17 & 1 & 1 & 5 & 28 & 72 & 0.496 & 0.48 \\
\hline 18 & 9 & 1 & 5 & 28 & 72 & 0.485 & 0.55 \\
\hline 19 & 1 & 9 & 5 & 28 & 72 & 0.513 & 0.54 \\
\hline 20 & 9 & 9 & 5 & 28 & 72 & 0.522 & 0.48 \\
\hline 21 & 1 & 1 & 8.5 & 28 & 72 & 0.548 & 0.51 \\
\hline 22 & 9 & 1 & 8.5 & 28 & 72 & 0.547 & 0.55 \\
\hline 23 & 1 & 9 & 8.5 & 28 & 72 & 0.559 & 0.56 \\
\hline 24 & 9 & 9 & 8.5 & 28 & 72 & 0.611 & 0.58 \\
\hline 25 & 1 & 1 & 5 & 45 & 72 & 0.654 & 0.56 \\
\hline 26 & 9 & 1 & 5 & 45 & 72 & 0.669 & 0.63 \\
\hline 27 & 1 & 9 & 5 & 45 & 72 & 0.721 & 0.60 \\
\hline 28 & 9 & 9 & 5 & 45 & 72 & 0.579 & 0.59 \\
\hline 29 & 1 & 1 & 8.5 & 45 & 72 & 0.617 & 0.61 \\
\hline 30 & 9 & 1 & 8.5 & 45 & 72 & 0.653 & 0.64 \\
\hline 31 & 1 & 9 & 8.5 & 45 & 72 & 0.681 & 0.65 \\
\hline 32 & 9 & 9 & 8.5 & 45 & 72 & 0.715 & 0.72 \\
\hline 33 & 0 & 5 & 6.75 & 36.5 & 60 & 0729 & 0.75 \\
\hline 34 & 14.51 & 5 & 6.75 & 36.5 & 60 & 0.766 & 0.79 \\
\hline 35 & 5 & 0 & 6.75 & 36.5 & 60 & 0 & 0 \\
\hline 36 & 5 & 14.51 & 6.75 & 36.5 & 60 & 1.051 & 0.98 \\
\hline 37 & 5 & 5 & 2.59 & 36.5 & 60 & 0 & 0.043 \\
\hline 38 & 5 & 5 & 10.21 & 136.5 & 60 & 0.284 & 0.15 \\
\hline 39 & 5 & 5 & 6.75 & 16.28 & 60 & 0.149 & 0.26 \\
\hline 40 & 5 & 5 & 6.75 & 56.72 & 60 & 0.544 & 0.27 \\
\hline 41 & 5 & 5 & 6.75 & 36.5 & 31.46 & 0.399 & 0.65 \\
\hline 42 & 5 & 5 & 6.75 & 36.5 & 88.54 & 0.572 & 0.65 \\
\hline 43 & 5 & 5 & 6.75 & 36.5 & 60 & 0.771 & 0.72 \\
\hline 44 & 5 & 5 & 6.75 & 36.5 & 60 & 0.696 & 0.72 \\
\hline 45 & 5 & 5 & 6.75 & 36.5 & 60 & 0.778 & 0.72 \\
\hline 46 & 5 & 5 & 6.75 & 36.5 & 60 & 0.779 & 0.72 \\
\hline 47 & 5 & 5 & 6.75 & 36.5 & 60 & 0.678 & 0.72 \\
\hline 48 & 5 & 5 & 6.75 & 36.5 & 60 & 0.714 & 0.72 \\
\hline 49 & 5 & 5 & 6.75 & 36.5 & 60 & 0.784 & 0.72 \\
\hline 50 & 5 & 5 & 6.75 & 36.5 & 60 & 0.784 & 0.72 \\
\hline
\end{tabular}

*The response $\mathrm{Y}$ was the mean value of these experiments 

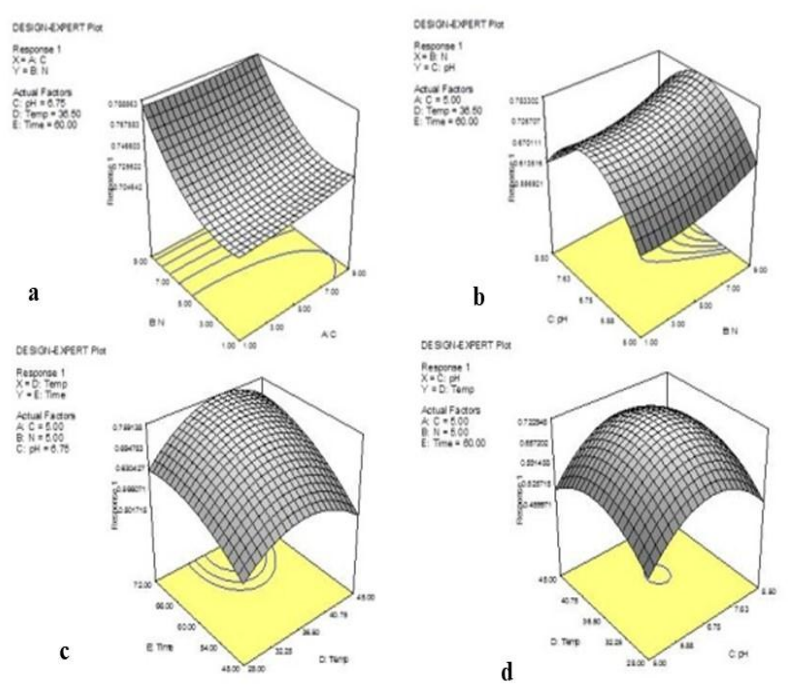

Figure 4: Three dimensional response surface curves for exopolysaccharide production plotted between (a) Lactose $(\% \mathrm{w} / \mathrm{v})$ and Yeast Extract (\% w/v) (b) $\mathrm{pH}$ and nitrogen source (c) temperature and $\mathrm{pH}$ (d) temperature and incubation time.

Analysis of variance (ANOVA) for Response Surface of AdF1, AdF2 and AdF3: Analysis of variance provided response (EPS production $(\mathrm{mg} / \mathrm{mL})$ ) as a function of the initial values of carbon source (lactose), nitrogen source (yeast extract), temperature, time and $\mathrm{pH}$. The coefficient of determination $\left(\mathrm{R}^{2}\right)$ was calculated as 0.9283 for EPS production by AdF1 (Table IV), indicating that the statistical model can explain $92.83 \%$ of variability in the response. In case of AdF2 the coefficient of determination $\left(\mathrm{R}^{2}\right)$ was calculated as 0.9337 for EPS production (Table V), indicating that the statistical model can explain $93.37 \%$ of variability in the response. While for AdF3 coefficient of determination $\left(\mathrm{R}^{2}\right)$ was calculated as 0.8532 for EPS production (Table VI), indicating that the statistical model can explain $85.32 \%$ of variability in the response. Since, the $\mathrm{R}^{2}$ value was obtained between 0 and 1 in all the cases, which indicated that the model was significant in predicting the response. The closer the $\mathrm{R} 2$ to 1.0 , the stronger the model and better it is predicted [61-62].

The purpose of statistical analysis is to determine the experimental factors, which generate signals that are large in comparison to the noise. The predicted R2 for AdF1, AdF2 and AdF3 was 0.6976, 0.7608 and 0.3898 , respectively which were also in reasonable agreement with the adjusted $\mathrm{R}^{2}$ (SM Table IV, V, VI). This indicates that there is a good agreement between the experimental and predicted values for EPS production. The adjusted R2, corrects the R2 (coefficient of determination) value for the sample size and for the number of items in the model. Adequate precision measures the signal to noise ratio. An adequate precision of 20.554, 21.579 and 14.940 was found for EPS production in case of AdF1, AdF2 and AdF3, respectively (A ratio greater than 4 is desirable). The value of predicted sum of squares (PRESS) is a measure of how a particular model fits each point in design. In this study in all three models, F-value and value of probability $>\mathrm{F}(<0.05)$ indicated that the model terms were significant.

\section{CONCLUSION}

In conclusion, this study provides the evidence for EPS production by the Enterococcus faecium isolated from the fermented foods of Western Himalayas. This study shows that RSM has significant positive effect on the EPS production. It also confers that for EPS production from Enterococcus faecium, lactose and yeast extract can act as best carbon and nitrogen sources and maximum EPS production can be obtained in the medium having $5 \%$ lactose, $14.51 \%$ yeast extract, having $\mathrm{pH} 6.75$ at $36.5^{\circ} \mathrm{C}$ after $60 \mathrm{~h}$ of incubation.

\section{ACKNOWLEDGEMENT}

The authors are thankful to the Department of Microbiology, CSK HP, Agricultural University, Palampur, for providing the facilities.

\section{Conflict of Interest}

The authors declare no conflict of interest.

\section{REFERENCES}

[1] S. S. Kanwar, M. K. Gupta, C. Katoch, "Cereal based traditional alcoholic beverages of Lahaul and Spiti area of Himachal Pradesh", Indian Journal of Traditional Knowledge, Vol.10, pp. 251-257, 2010.

[2] R. K. Singh, H. W. Chang, D. Yan, K. M. Lee, D. Ucmak, K. Wong, M. Abrouk, B. Farahnik, M. Nakamura, T. Zhu, T. Bhutani, W. Liao, "Influence of diet on the gut microbiome and implications for human health", Journal of Translational Medicine, Vol. 15 pp.73, 2017.

[3] H. Hassanzadazar, A. Ehsani, "Phenotypic characterization of lactic acid bacteria isolated from traditional koopeh cheese", Global Veterinaria, Vol.10 pp.148-152, 2013.

[4] S. Patel, A. Majumder, A. Goyal, "Potentials of Exopolysaccharides from lactic acid bacteria", Indian Journal of Microbiology, Vol. 52, pp. 3-12, 2012.

[5] S. R. K. Kanamarlapudi, S. Muddada, "Characterization of Exopolysaccharide Produced by Streptococcus thermophilus CC30”, BioMed Research International, (2017) https://doi.org/10.1155/2017/4201809.

[6] E. B. Hansen, "Commercial bacterial starter cultures for fermented foods of the future", International Journal of Food Microbiology, Vol. 78, pp. 119-131, 2002.

[7] D. Czerucka, T. Piche, P. Rampal, "Yeast as probiotics Saccharomyces boulardii", Aliment Pharmacology Therapy, Vol. 26, pp.767-778, 2007. 
[8] S. Galle, E. K. Arendt, "Exopolysaccharides from sourdough lactic acid bacteria", Critical Reviews in Food Science and Nutrition, Vol. 54, pp. 7, 2014.

[9] A. Patel, J. B. Prajapati, "Food and Health Applications of Exopolysaccharides produced by Lactic acid Bacteria", Adv Dairy Res, Vol. 1, pp.107, 2013.

[10] A. Kuntiya, P. Hanmoungjai, C. Techapun, K. Sasaki, P. Seesuriyachan, "Influence of $\mathrm{pH}$, sucrose concentration and agitation speed on exopolysaccharide production by Lactobacillus confusus TISTR 1498 using coconut water as a raw material substitut, Maejo" International Journal of Science and Technology, Vol. 4, pp. 318-330, 2010.

[11] S. Jorge-Ignacio, B. Martinez, R. Guillen, R. Jimenez-Diaz, A. Rodriguez, "Culture conditions determine the balance between two different exopolysaccharides produced by Lactobacillus pentosus lps26", Applied and Environmental Microbiology, Vol. 72, pp.7495-7502, 2006.

[12] P. Ruas-Madiedo, R. C. G. de-los, "Methods for the screening, isolation and characterization of exopolysaccharides produced by lactic acid bacteria", Journal of Dairy Scences, Vol. 88, pp.843856, 2005.

[13] P. Sanalibaba, G. A. Cakmak, "Exopolysaccharides Production by Lactic Acid Bacteria", Appli Micro Open Access, Vol. 2, pp.1000115, 2016.

[14] L. Jolly, S. J. Vincent, P. Duboc, J. R. Neeser, "Exploiting exopolysaccharides from lactic acid bacteria", Antonie Van Leeuwenhoek, Vol. 82, pp. 367-374, 2002.

[15] P. Duboc, B. Mollet, "Applications of exopolysaccharides in dairy industry", International Dairy Journal, Vol. 11, pp.759-768, 2001

[16] S. Chabot, "Exopolysaccharides from Lactobacillus rhamnous $R W$ 9595M stimulate TNF, IL-6 and IL-12 in human and mouse cultured immunocompetent cells and IFN-c in mouse splenocytes", Dairy Science and Technology, Vol. 81, pp. 683-697, 2001.

[17] P. J. Looijesteijn, J. Hugenholtz, "Uncoupling of growth and exopolysaccharide production by Lactococcus lactis subsp. cremoris NIZO B40 and optimization of its synthesis", Journal of Bioscience and Bioengineering, Vol. 88 pp.178-182, 1999.

[18] A. D. Welman , I. S. Maddox, "Exopolysaccharides from lactic acid bacteria: perspectives and challenges", Trends in Biotechnology, Vol. 21, pp.269-274, 2003.

[19] H. J. Ruijssenaars , F. Stingele, S. Hartmans , "Biodegradability of food-associated extracellular polysaccharides", Current Microbiology, Vol. 40, pp.194-199, 2000.

[20] A. Sourabh, S. S. Kanwar, P. N. Sharma, "Diversity of bacterial probiotics in traditional fermented foods of western Himalaya", International Journal of Probiotics and Prebiotics, Vol. 5, pp.193202, 2010.

[21] A. Khuri, S. Mukhopadhyay, "Response surface methodology", WIREs Computational Statistics, Vol. 2, pp. 128-149, 2010

[22] D. Mora, M. G. Fortina, C. Parini, G. Ricci, M. Gatti, G. Giraffa, P. L. Manachini, "Genetic diversity and technological properties of Streptococcus thermophilus strains isolated from dairy products", Journal of Applied Microbiology, Vol. 93, pp. 278-287, 2002.

[23] M. Dubios, K. A. Gilles, J. K. Hamilton, P. A. Rebers, F. Smith, "Colorimetric method for determination of sugars and related substances", Analytical Chemistry, Vol. 28, pp. 350-356, 1956.

[24] J. Prasanna, L. Karunamoorthy, M. Venkat Raman, S. Prashanth, D. Raj Chordia, "Optimization of process parameters of small hole dry drilling in Ti-6AI-4V using Taguchi and grey relational analysis", Measurement, Vol. 48, pp. 346-354, 2014.

[25] L. De Vuyst, B. Degeest, "Heteropolysaccharides from lactic acid bacteria", FEMS Microbiology Reviews, Vol. 23, pp. 153-177, 1999.

[26] A. M. Fialho , L. M. Moreira , A. T. Granja , A. O. Popescu , K.. Hoffmann , I Sa-Correia, "Occurrence, production and applications of gellan: current state and perspectives", Applied Microbiology and Biotechnology, Vol. 79, pp. 889-900, 2008.

[27] B. H. A. Rehm, "Bacterial polymers: biosynthesis, modifications and applications", Nature Reviews Microbiology, Vol. 8, pp. 578$\mathbf{5 9 2 ,} 2010$.

[28] A. S. Kumar, K. Mody, B. Jha , "Bacterial exopolysaccharides-a perception", Journal of Basic Microbiology, Vol. 47, pp.103-117, 2007.

[29] M. Ullrich, "Bacterial Polysaccharides: Current Innovations and Future Trends", (Caister Academic Press, UK), Inc.p 358, 2009.

[30] R. Tallon , P. Bressollier , M. C. Urdaci , "Isolation and characterization of two exopolysaccharides produced by Lactobacillus plantarum EP56", Research in Microbiology", Vol. 154, pp. 705-712, 2003.

[31] S. Matsumoto, T. Hara , T. Hori , K. Mitsuyama, M. Nagaoka , N. Tomiyasu , A. Suzuki , M. Sata , "Probiotic Lactobacillus-induced improvement in murine chronic inflammatory bowel disease is associated with the downregulation of pro-inflammatory cytokines in lamina propria mononuclear cells", Clinical and Experimental Immunology, Vol. 140, pp. 417-426, 2005.

[32] A. H. El-Saggan , B. Uhrik, "Improved staining of negative binding sites with ruthenium red on cryosections of frozen cells", General Physiology and Biophysics, Vol. 21, pp. 457-46, 2002.

[33] G. E. Gardiner, R. P. Ross, J. M. Wallace, F. P. Scanlan, P. P. Jagers, G. F. Fitzgerald, J. K. Collins, C. Stanton, "Influence of a probiotic adjunct culture of Enterococcus faecium on the quality of Cheddar cheese", Journal of Agricultural and Food Chemistry, Vol. 47, pp. 4907-4916, 1999.

[34] G. Giraffa, "Functionality of Enterococci in dairy products", International Journal of Food Microbiology, Vol. 88, pp. 215-222, 2003.

[35] F. Mozzi, F. Vaningelgem, E. M. Hebert, R. V. Meulen, M. R. F . Moreno, G. F. Valdez, L. D. Vuyst, "Diversity of Heteropolysaccharide-Producing Lactic Acid Bacterium Strains and Their Biopolymers", Applied Environmental Microbiology, Vol. 72, pp. 4431-4435, 2006.

[36] P. Kanmani , K. Suganya , R.S. Kumar , N. Yuvaraj , V. Pattukumar, K. A. Paari , V. Arul, "Synthesis and functional characterization of antibiofilm exopolysaccharide produced by Enterococcus faecium MC13 isolated from the gut of fish", Applied and Biochemistry Biotechnology, Vol. 169, pp.1001-1015, 2013.

[37] X. Rihua, M. Shimin, W. Yang, L. Lisha, L. Pinglan, "Screening, identification and statistic optimization of a novel exopolysaccharide producing Lactobacillus paracasei", African Journal of Microbiology Research, Vol. 4, pp. 783-795, 2010.

[38] T. Sivakumar, S. Sivasankara-Narayani, T. Shankar, Vijayabaskar, "Optimization of cultural conditions for exopolysaccharides produced by Frateuria aurantia", International Journal of Applied and Pharmaceutial Technology, Vol. 3, pp. 133-143, 2012.

[39] S. Abdulrazack, V. Velayutham, V. Thangavelu, "Medium optimization for the production of exopolysaccharide by Bacillus subtilisusing synthetic sources and agro wastes", Turkish Journal Biology, Vol. 37, pp. 280-288, 2013.

[40] B. Ismail, M. K. Nampoothiri, "Exopolysaccharide production and prevention of syneresis in starch using encapsulated probiotic Lactobacillus plantarum", Food Technology and Biotechnoogy, Vol. 48, pp. 484-489, 2010.

[41] P. Vijayabaskar, S. Babinastarlin, Shankar, T. Sivakumar, K. T. K. Anandapandian, "Quantification and characterization of exopolysaccharides from Bacillus subtilis (MTCC121)", Advances in Biological Research, Vol. 5, pp. 71-76, 2011.

[42] B. Peant, La-Pointe, C. Gilbert, D. Atlan, P. Waed, D. Roy, "Comparative analysis of the exopolysaccharide biosynthesis gene clusters from four strains of Lactobacillus rhamnosus", Microbiology, Vol. 151, pp.1839-1851, 2005. 
[43] C. Datta, P. S. Basu, "Production of extracellular polysaccharides by a Rhizobium species from root nodules of Cajanuscajan", Acta Biotechnologica, Vol. 19, pp. 59-68, 1999.

[44] P. S. Peiris, A. M. Dlamini, H. J. Bavor, "Optimization of bioprocess conditions for exopolysaccharide production by Klebsiella oxytoca", World Journal of Microbiologyand Biotechnology, Vol. 14 pp. 917-919, 1998.

[45] N. Habibi, S. Soleimanian-Zad, S. Z. Mohammad, "Exopolysaccharides produced by pure culture of Lactobacillus, Lactococccus and Yeast isolated from kefir grain by Microtiter Plate Assay: Optimization and comparision", World Applied Sciences Journal, Vol. 12, 742-750, 2011.

[46] S. B. Liu , L. P. Qiao, H. L. He , Q. Zhang, X. L. Chen , W. Z. Zhou, B. C. Zhou, Y. Z. Zhang, "Optimization of fermentation conditions and rheological properties of exopolysaccharide produced by deep-sea bacterium Zunongwangia profunda SMA87', PLoS One, Vol. 6, pp. 213-235, 2011.

[47] H. Hwang, S. Kim, J. Lim, J. Joo, H. Kim, H. Kim, J. Yun, "Hypoglycemic effect of crude exopolysaccharides produced by a medicinal mushroom Phellinus baumii in streptozotocin-induced diabetic rats", Life Sciences, Vol. 76, pp. 3069- 3080, 2005.

[48] S. Jeeva, T. Selva-Mohan, A. Palavesam, N. C. J. Packia-Lakshmi, J. Raja-Brindh, "Production and optimization study of a Novel Extracellular Polysaccharide by wild-type isolates Of Xanthomonas campestris", Journal of Microbiology and Biotechnology Research, Vol. 1, pp. 175-182, 2011.

[49] J. B. Sutherland, A. L. Selby, J. P. Freeman, F. E. Evans, C. E. Cerniglia, "Metabolism of phenanthrene by Phanerochaete chrysosporium", Applied and Environmental Microbiology, Vol. 57, pp. 113310-3316, 1991.

[50] W Crueger, A Cruegr, "Substratos para la fermentation industrial", Journal of Dairy Research, Vol. 42, pp. 123-138, 1993.

[51] S. V. Patil , R. B. Salunkhe , C. D. Patil, D. M. Patil , B. K. Salunke, "Bioflocculant exopolysaccharide production by Azotobacter indicus using flower extract of Madhuca latifolia L", Applied Biochemistry and Biotechnology, Vol. 162, pp. 1095-1099, 2010.

[52] C. C. Tong, K. Rajendra, "Effect of carbon and nitrogen sources on the growth and production of cellulase enzymes of a newly isolated Aspergillus sp.", Pertanika, Vol. 15, pp. 45-50, 1992.

[53] G. Selvakumar, S. Kundu, A. D. Gupta, Y. S. Shouche, H. S. Gupta, "Isolation and characterization of non rhizobial plant growth promoting bacteria from nodules of Kudzu (Puerariathunbergiana) and their effect on wheat seedling growth", Current Microbiology, Vol. 56, pp. 134-139, 2008.

[54] R. Gupta, P. Gigras, H. Mohapatra, V. K. Goswami, B. Chauhan, "Microbial alpha amylase: a biotechnological perspective", Process Biochemistry, Vol. 38, pp.1599-1616, 2003.

[55] F. P. Duta, F. P. de Franca, L. L. M. de-Almeida, "Optimization of culture conditions for exopolysaccharides production in Rhizobium sp. using the Response Surface Method", Electronic Journal of Biotechnology, Vol. 9, pp. 317-347, 2005.

[56] T. Sivakumar, S. Sivasankara-Narayani, T. Shankar, Vijayabaskar, "Optimization of cultural conditions for exopolysaccharides produced by Frateuria aurantia", International Journal of Applied and Pharmaceutial Technology, Vol. 3, pp. 133-143, 2012.

[57] J. Muralidharan, S. Jayachandran, "Physiochemical analyses of the exopolysaccharides produced by a marine biofouling bacterium, Vibrio aliginolyticus", Process Biochemistry, Vol. 38, pp. 841-847, 2003.

[58] D. C. Boyle, A. E. Read, "Characterization of two extracellular polysaccharides from marine bacteria", Applied and Environmental Microbiololgy, Vol. 46, pp. 392-399, 1983.
[59] Y. Zhang, S. Li, C. Zhang, Y. Luo, H.. Zhang, Z Yang, "Growth and exopolysaccharide production by Lactobacillus fermentum F6 in skim milk", African Journal of Biotechnology, Vol. 10, pp. 20802091, 2011.

[60] J. L. U. M. Rao, T. Satyanarayana, "Statistical optimization of a high maltose forming, hyperthermostable and $\mathrm{Ca}^{2+}$ independent alpha-amylase production by an extreme thermophile Geobacillus thermoleovorans using response surface methodology", Journal of Applied Microbiology, Vol. 95, pp. 712-718, 2003.

[61] L. Qiang, L. Yumei, H. Sheng, L. Yingzi, S. Dongxue, H. Dake, W. Jiajia, Q. Yanhong, Z. Yuxia, "Optimization of fermentation conditions and properties of an exopolysaccharide from Klebsiella sp. H-207 and application in adsorption of hexavalent chromium", PLoS One, Vol. 8, e53542, 2013.

[62] P. D. Haaland, "Statistical problem solving, in: Experimental design in biotechnology", edited by Haaland P. D., (Marcel Dekker, Inc, New York), pp. 1-18, 1989. 